\title{
Antibacterial and Antioxidant Activities of Ginger Essential Oils
}

\author{
MEGA FERDINA WARSITO*, FEBRIANA UNTARI, ANGGIA PRASETYOPUTRI, \\ FAUZY RACHMAN, ERIS SEPTIANA, ASEP BAYU, AKHIRTA ATIKANA, \\ LINDA SUKMARINI*, AND MASTERIA YUNOVILSA PUTRA
}

\author{
Research Center for Biotechnology, National Research and Innovation Agency (BRIN), \\ Jalan Raya Bogor KM. 46, Cibinong 16911, Indonesia.
}

\begin{abstract}
Ginger is a rhizomatous perennial herb that grows abundantly in tropical areas. It has been used around the world as a spice, flavoring agent, and ingredient in traditional medicine. Ginger essential oils (GEOs) are derivatives of ginger that can be found in various products used in daily life, such as food, pharmaceutical, and cosmetics. The present study analyzed the chemical compositions, antioxidant, and antibacterial activities of three commercially available GEOs. The compositions of GEOs were identified using the gas chromatography method. The antioxidant activity was evaluated using 2,2-diphenyl-1-picryl-hydrazyl (DPPH) and 2,2'-azinobis- (3ethylbenzothiazoline-6-sulfonic acid) (ABTS) assay methods. The antibacterial activity was determined using a disc diffusion assay based on the diameter of the inhibition zone (DIZ). The main compounds identified from the samples were zingiberene, $\alpha$-curcumene, $\beta$-sesquiphellandrene, camphene, $\alpha$-farnesene, $\beta$-bisabolene, $\alpha$-pinene, and 3-carene. The $\mathrm{IC}_{50}$ values were found to be 5.3023 and $1.4504 \mathrm{mg} \mathrm{mL}^{-1}$ for GEO1; 0.9249 and $0.5276 \mathrm{mg} \mathrm{mL}^{-1}$ for GEO2; and 10.4463 and $3.3535 \mathrm{mg} \mathrm{mL}^{-1}$ for GEO3 when evaluated using DPPH and ABTS assay methods, respectively. All samples showed antibacterial activity against Staphylococcus aureus ATCC 13420 and Bacillus subtilis (the collection of National Research and Innovation Agency), while only GEO2 and 3 displayed inhibitory effect against Escherichia coli ATCC 9637.
\end{abstract}

Key words: antibacterial, antioxidant, chemical composition, essential oil, ginger

Jahe adalah tumbuhan rhizoma herba perennial yang banyak ditemukan di daerah tropis. Tanaman ini banyak digunakan sebagai rempah, perisa, maupun bahan baku untuk obat tradisional. Minyak jahe, merupakan salah satu produk turunan jahe, yang telah banyak digunakan dalam produk-produk yang digunakan dalam kehidupan sehari-hari seperti makanan, produk farmasi, dan kosmetik. Artikel ini memberikan informasi mengenai komponen kimia, aktivitas antioksidan, dan antibakteri dari minyak jahe komersial. Senyawa kimia dari minyak jahe dianalisa dengan metode kromatografi gas. Aktivitas antioksidan sampel diuji dengan metode uji 2,2diphenyl- 1-picryl-hydrazyl (DPPH) dan 2,2'-azinobis-(3-ethylbenzothiazoline-6-asam sulfonat) (ABTS). Sedangkan aktivitas antibakteri dianalisa dengan menggunakan metode difusi cakram, dengan mengukur zona hambat yang terbentuk. Senyawa kimia utama yang terdeteksi dalam sampel adalah zingiberen, $\alpha$-curcumen, $\beta$ sesquifellandren, camphen, $\alpha$-farnesen, $\beta$-bisabolen, $\alpha$-pinena, dan 3-karena. $\mathrm{IC}_{50}$ sampel yang diperoleh adalah 5.3023 dan $1.4504 \mathrm{mg} \mathrm{mL}^{-1}$ untuk GEO1; 0.9249 dan $0.5276 \mathrm{mg} \mathrm{mL}^{-1}$ untuk GEO2; serta 10.4463 dan $3.3535 \mathrm{mg}$ $\mathrm{mL}^{-1}$ untuk sampel GEO3 ketika diuji dengan metode DPPH dan ABTS, secara berurutan. Semua sampel menunjukkan aktivitas antibakteri terhadap Staphylococcus aureus ATCC 13420 dan Bacillus subtilis (koleksi Badan Riset dan Inovasi Nasional), sedangkan hanya GEO2 dan GEO3 yang menunjukkan aktivitas penghambatan terhadap Escherichia coli ATCC 9637.

Kata kunci: antibakteri, antioksidan, jahe, komponen kimia, minyak atsiri

Zingiberaceae belongs to a large family of monocotyledonous perennial herbs. This plant is widely cultivated in tropical and subtropical regions (Kun-Hua et al. 2011), encompassing approximately 50 genera and more than 1,200 species (Pintatum et al. 2020). Ginger has been used widely as a spice, flavoring agent, and traditional remedy (Abd El-Hack et al. 2020). Studies revealed that ginger had various pharmacological activities, such as antioxidant, antimicrobial, gastrointestinal modulating agent,

*Corresponding author: Phone: +62-21-8754587, Fax. +6221-8754588; E-mail: mferdina@gmail.com; linda.sukmarini @lipi.go.id antidiabetic, anticancer, antivomiting, neuroprotection, anti-inflammation, cardiovascular protector, antiobesity, antinausea, anti-emetic, protective effects against respiratory disorders, and analgesic (Mao et al. 2019; Abd El-Hack et al. 2020; Anh et al. 2020). Ginger essential oil (GEO) is one of ginger derivatives that can be found in various products, such as food, pharmaceutical, and cosmetics. Diverse biological activities of GEO have also been reported in various studies, such as antimicrobial, antioxidant, analgesic, anti-inflammatory, bronchodilator, anti-ulcer, anticancer, and immunomodulatory (Mahboubi 2019).

The yields of essential oil from ginger rhizomes 
range between 1-5\% (Bampidis et al. 2020). Factors that affected the yields were the source, freshness, and the treatment (drying method) of rhizomes, as well as the distillation methods. The chemical constituents of GEO primarily consist of monoterpenes, sesquiterpenes hydrocarbons, oxygenated sesquiterpenes, and phenylpropanoid compounds (Mahboubi, 2019; Pintatum et al. 2020). Similar to the yields, the chemical compositions of the GEOs can greatly be affected by several factors i.e., the source of rhizome, its freshness or dryness, and the extraction methods used (Mahboubi 2019). GEO is mainly obtained from Zingiber officinale, although other sources of Zingiberaceae family are also available, such as Z. zerumbet (Koga et al. 2016; Rana et al. 2017), Z. cassumunar (Bhuiyan et al. 2008), Z. montanum (Manochai et al. 2010), and $Z$. kerrii (Pintatum et al. 2020).

The urgent need for antibiotics to overcome resistant bacteria underlines the importance of developing new antibiotics, one of which is by sourcing the lead compounds from natural products, including essential oils. Similarly, the demands for natural food preservatives, as well as natural antioxidants for the cosmetic and food industry, are increasing. Antioxidant activity of natural products is also of interest and has been investigated for its correlation to diseases, as the production of free radicals in the body correlates with various human diseases (Lobo et al. 2010). As ginger has been used as traditional medicine and its medicinal properties have been widely investigated, its essential oils may be a promising source of these properties. Therefore, this study aimed to elucidate the antibacterial and antioxidant activities of three different commercial GEOs.

\section{MATERIALS AND METHODS}

Procurement of GEOs. The essential oils of ginger were obtained through online commerce.

Gas Chromatography-Mass Spectrometry Analysis. The GC-MS analysis of GEO was conducted using GC/MS apparatus (Shimadzu QP 2010 Ultra, Japan) equipped with a low polarity column (30 m x $0.25 \mathrm{~mm} \times 0.25 \mu \mathrm{m}$; Restek-5MS, USA). Helium as the carrier gas was set at a flow rate of $0.98 \mathrm{~mL} \mathrm{~min}^{-1}$. The column temperature was raised to $80^{\circ} \mathrm{C}$ and kept for 3 min and steadily rose at $7.50{ }^{\circ} \mathrm{C} \min ^{-1}$ to $220{ }^{\circ} \mathrm{C}$ and held for $5 \mathrm{~min}$, followed by a temperature increment of $10{ }^{\circ} \mathrm{C} \mathrm{min}^{-1}$ rate and kept for $5 \mathrm{~min}$ at $270{ }^{\circ} \mathrm{C}$. The prepared samples (10\% GEO in ethanol) were injected at $8 \mu \mathrm{L}$ with a split ratio of 1:50. The peaks were identified by a combined search of retention time and comparison of MS fragments of the peak with mass spectra (NIST 14 library). The percentages are calculated from the peak areas given by the GC-MS.

Antibacterial Activity. The inhibitory effect of pure (100\%) GEOs was tested using agar disc diffusion method against Escherichia coli ATCC 9637 (Supelco, Sigma Aldrich), Bacillus subtilis (collection of Indonesia Institute of Sciences), and Staphylococcus aureus ATCC 13420 (Supelco, Sigma Aldrich). The bacterial suspension was prepared using freshly grown bacteria in Nutrient Broth (NB; Merck) that was incubated at $37{ }^{\circ} \mathrm{C}$ overnight with shaking at $180 \mathrm{rpm}$. The inoculum was diluted in liquid Nutrient Agar (NA; Merck) to achieve optical density (OD) of 0.02 or $5 \times 10^{7} \mathrm{CFU} \mathrm{mL}{ }^{-1}$ at $600 \mathrm{~nm}$. The inoculated NA was then poured into disposable petri dishes (SPL Life Sciences) and left to set. All samples and positive controls were applied to the blank paper discs (Fioroni Filters) at $10 \mu \mathrm{L}$ and left to dry. As positive controls, streptomycin sulphate (Merck) was used for B. subtilis $(5 \mu \mathrm{g})$, whereas ampicillin (Merck) was used for $E$. coli $(10 \mu \mathrm{g})$ and $S$. aureus $(3 \mu \mathrm{g})$. The diameter of the inhibition zone (DIZ) was measured after 18-24 h incubation at $37^{\circ} \mathrm{C}$.

2,2-Diphenyl-1-picryl-hydrazyl (DPPH) Assay. The DPPH assay was conducted based on a method described by Yen and Chen (1995) with slight modifications. Briefly, stock solution of GEOs was prepared by diluting the samples in methanol to get concentration of $100 \mu \mathrm{g} \mathrm{mL}^{-1}$. A total of $40 \mu \mathrm{L}$ of a solution of $1 \mathrm{mM}$ DPPH in methanol was mixed with a volume of GEO stock solution adjusted for a series of concentration and then added methanol to a final volume of $200 \mu \mathrm{L}$ to get the the desired concentration. The solution was incubated for $30 \mathrm{~min}$ in the dark at room temperature. The absorbance of five concentration levels of the samples were measured at $515 \mathrm{~nm}$ using a microplate reader (Tecan Infinite M200 Pro, Switzerland). Negative and positive controls were methanol and ascorbic acid (AA) (Merck), respectively. The inhibition percentage of the samples was calculated according to the following formula:

$$
\% \text { Inhibition }=\frac{\left(A_{\text {biank }}-A_{\text {sample }}\right)}{A_{\text {biank }}} \times 100 \%
$$

2,2'-Azinobis-(3-ethylbenzothiazoline-6sulfonic acid) (ABTS) Assay. The ABTS radical scavenging assay method was adopted from Lyu et al. (2020) with minor modifications. The radical mono cation of ABTS was prepared by mixing $7.4 \mathrm{mMABTS}$ with $2.6 \mathrm{mM}$ potassium persulfate at 1:1 ratio, the 
solution was incubated for $24 \mathrm{~h}$ in the dark at room temperature. The ABTS solution was diluted with phosphate-buffered saline $(\mathrm{pH}$ 7.4) to obtain an absorbance of $0.7 \pm 0.02$ at $734 \mathrm{~nm}$. Aliquots of samples $(10 \mu \mathrm{L})$ at five concentration levels were reacted with $190 \mu \mathrm{L}$ of the ABTS solution and incubated for $6 \mathrm{~min}$. Trolox was used as the positive control. The absorbance was measured at $734 \mathrm{~nm}$ using the Tecan Infinite M200 Pro. Antioxidant activities were calculated based on the equation below:

$$
\% \text { Inhibition }=\frac{\left(A_{\text {biank }}-A_{\text {sampie }}\right)}{A_{\text {biank }}} \times 100 \%
$$

The $\mathrm{IC}_{50}$ value shows the concentration of sample that is able to inhibit the oxidation process by $50 \%$ obtained by making a linear curve between the concentration of the test solution (x-axis) and \% antioxidant activity (y-axis).

Statistical Analysis. The statistical analysis was evaluated using SPSS version 22 (SPSS Inc.). The results were expressed as mean \pm SD (standard deviation). Pearson's correlation test was used to assess correlations between means. One-way analysis of variance was performed by ANOVA and followed by Tukey's multiple comparison tests. $\mathrm{P}<0.05$ was regarded as significant.

\section{RESULT}

\section{GC-MS Analysis-Based Chemical} Compositions. Fig 1 represents the total ion chromatogram (TIC) of three commercial GEO samples that resume intensities of all mass spectral peaks pertaining to the same scan. Based on comparing retention time-MS fragments of the sample peaks with the mass spectra of a computer based-NIST 14 library, the chemical compounds detected in the commercial GEOs tested and are listed in Table 1. It is shown that the major compounds of GEO1 were $\alpha$-zingiberene $(22.89 \%)$, camphene $(16.94 \%), \alpha$-curcumene $(11.62 \%), \beta$-sesquiphellandrene $(11.21 \%), \beta$ bisabolene (9.07\%), $\alpha$-pinene (5.04), and $\alpha$-farnesene $(4.46 \%)$. Moreover, GEO2 had $\alpha$-pinene $(25.72 \%)$ as the main component, followed by $\alpha$-curcumene (11.88\%), $\alpha$-zingiberene (8.01\%), 3-carene $(7.71 \%), \beta$ sesquiphellandrene $(6.81 \%), \beta$-bisabolene $(6.24 \%)$, and ar-tumerone (4.65\%). While in GEO3, the major identified compounds were $\alpha$-zingiberene $(24.88 \%), \beta$ sesquiphellandrene (13.67\%), $\beta$-bisabolene $(11.20 \%)$, $\alpha$-curcumene $(10.68 \%), \alpha$-farnesene $(6.93 \%)$, camphene $(5.08 \%)$, cis-sabinene $(4.35 \%)$.

Antibacterial Activity. In this study, all samples were tested for antibacterial activities against $E$. coli ATCC 9637, B. subtilis (collection of LIPI), and $S$. aureus ATCC 13420. Table 2 displays the extent of antibacterial activities of GEOs compared to the antibiotic controls when tested at a concentration of $100 \%$ with a volume of $10 \mu \mathrm{L}$. The antibacterial activities were measured based on the formation of DIZ and recorded in millimetres $(\mathrm{mm})$. The results were categorized as follows: a DIZ of $<10 \mathrm{~mm}$ was taken as weak inhibition, a DIZ of $10-15 \mathrm{~mm}$ was taken as moderate inhibition, a DIZ of $16-20 \mathrm{~mm}$ was considered as strong inhibition, and above $25 \mathrm{~mm}$ was deemed as a very strong inhibition. GEO 2 and GEO 3 showed weak antimicrobial activity against all tested microorganisms, i.e., S. aureus, E. coli, and B. subtilis. On the other hand, GEO 1 exhibited a weak activity only against the Gram-positive bacteria, namely $S$. aureus and B. subtilis.

Antioxidant Activity. The antioxidant activity of GEOs expressed as $\mathrm{IC}_{50}$ values is illustrated in Figure 2. The $\mathrm{IC}_{50}$ values of GEO1, GEO2, and GEO3 when evaluated using DPPH assay (Figure 2a) were 5.3023 \pm $0.1486 \mathrm{mg} \mathrm{mL}^{-1}, 0.9249 \pm 0.0138 \mathrm{mg} \mathrm{mL}^{-1}, 10.4463 \pm$ $0.4662 \mathrm{mg} \mathrm{mL}^{-1}$, respectively. While the $\mathrm{IC}_{50}$ values when assessed using ABTS assay (Figure $2 b$ ) were $1.4504 \pm 0.0551 \mathrm{mg} \mathrm{mL}^{-1}, 0.5276 \pm 0.0107 \mathrm{mg} \mathrm{mL}^{-1}$, and $3.3535 \pm 0.1601 \mathrm{mg} \mathrm{mL}^{-1}$ for GEO1, GEO2, and GEO 3, respectively. A similar pattern was observed with both methods as GEO2 displayed the highest overall antioxidant activity, while GEO3 exhibited the least activity. Overall, all the GEOs tested had significantly lower anti-radical scavenging activity ( $p$ $<0.05$ ) compared to the positive control used in the tests, ascorbic acid $\left(\mathrm{IC}_{50}=0.0059 \pm 0.0002 \mathrm{mg} \mathrm{mL}^{-1}\right)$ in the DPPH assay and trolox $\left(\mathrm{IC}_{50}=0.0054 \pm 0.0001 \mathrm{mg}\right.$ $\left.\mathrm{mL}^{-1}\right)$ in the ABTS assay.

\section{DISCUSSION}

The complex and various constituents of essential oils, including GEOs, possess a wide array of biological properties (Miguel, 2010), including antimicrobial and antioxidant properties of GEOs (Bellik 2014; Mahboubi 2019; Wang et al. 2020). The urgent need to find new sources of antimicrobial compounds and the demands for naturally-sourced preservatives are a few reasons why GEO and other essential oils are often investigated for their antimicrobial and antioxidant properties. This present study aims to characterise the chemical constituents of three commercially-available GEOs and elaborate on 


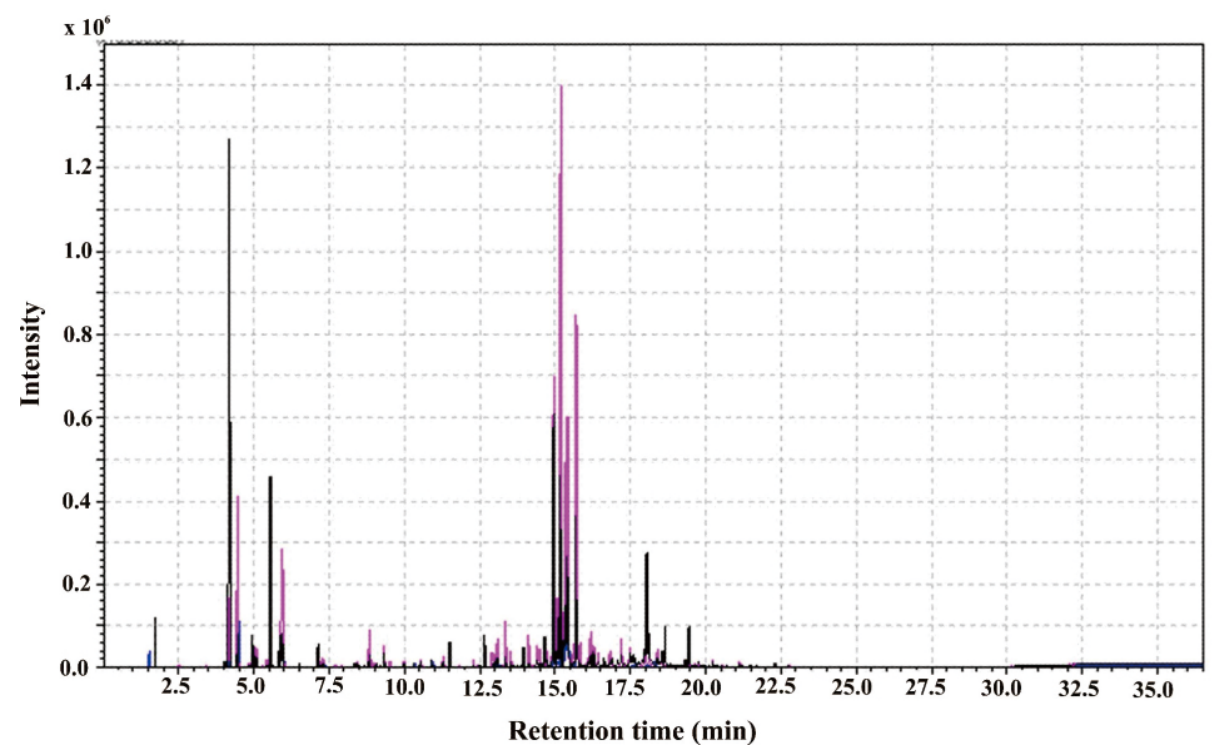

Fig 1 Total ion chromatogram of GEOs. $($ Blue $=$ GEO1; Black=GEO2; Pink=GEO3).

(a) DPPH

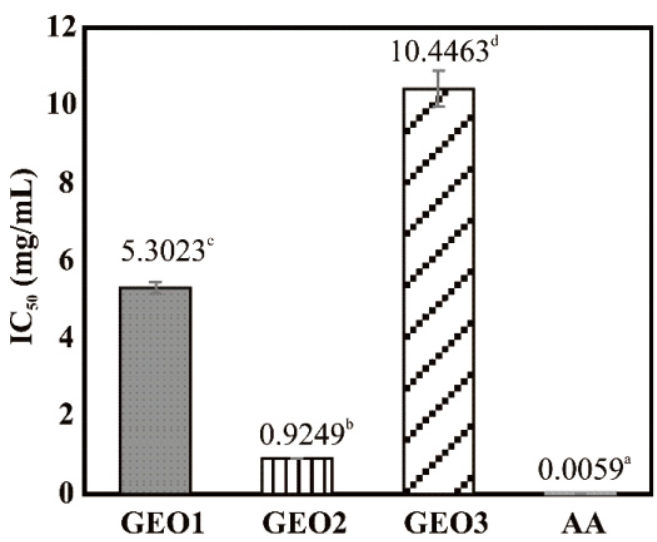

(b) ABTS

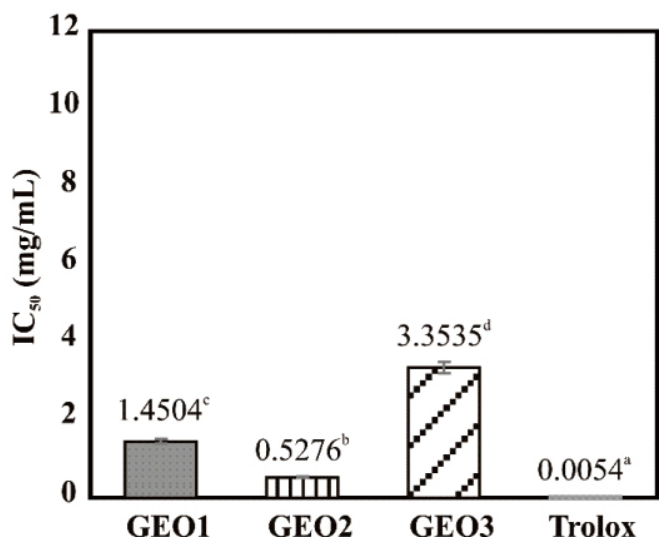

Fig 2 Antioxidant activity of GEOs based on the (a) DPPH and (b) ABTS methods. The numbers in each bar followed by the same letter are not significantly different at the 0.05 level of Tukey's multiple comparison tests.

their antibacterial and antioxidant properties.

It was known from the label and/or website of the ecommerce that GEO1 and GEO3 were produced from the root part of $Z$. officinale R., while the GEO3 source was unknown or not mentioned. Previous studies revealed that the major component of $Z$. officinale is zingiberene (Kamaliroostaa et al. 2013; Ribeiro et al. 2015; Sharma et al. 2016; Mahboubi, 2019). Those were different from GEO2, which contained $\alpha$-pinene as the major component (25.72\%). A study by Pintatum et al. (2020) also identified $\alpha$-pinene as the main component of $Z$. kerrii essential oil, suggesting the presence of $\alpha$-pinene can be used as the basis of identifying the source of GEO within Zingiberaceae family members with a high content of $\alpha$-pinene.

GEO has been reported to have various pharmacological and biological activities, including antimicrobial and antioxidant activities (Mahboubi, 2019). GEO has shown antimicrobial activity against S. aureus, Listeria monocytogenes, Pseudomonas aeruginosa, B. subtilis, E. coli, Acinetobacter baumannii, S. pyogenes, S. typhi, and multidrugresistant (MDR) A. baumannii (Stoyanova et al. 2006; Mesomo et al. 2013; Meliani et al. 2014; Wang et al. 2020). In this study, weak inhibitory effects against $E$. coli ATCC 9637, B. subtilis, and S. aureus ATCC 13420 were observed in all samples (Table 2). This finding was similar to earlier studies conducted by Bag and Chattopadhyay (2015) and Mostofa et al. (2018). On the other hand, a number of studies reported good antimicrobial activity (Sivasothy et al. 2011; Silva et al. 2018; Mahboubi, 2019), which suggested that the 
Table 1 Chemical compositions of the commercial GEOs

\begin{tabular}{|c|c|c|c|c|c|}
\hline \multirow{2}{*}{ No. } & \multirow{2}{*}{ Rt (min) } & \multirow{2}{*}{ Compounds } & \multicolumn{3}{|c|}{$\%$ Area } \\
\hline & & & GEO1 & GEO2 & GEO3 \\
\hline 1 & 4.021 & Tricyclene & 0.53 & - & - \\
\hline 2 & 4.191 & $\alpha$-Pinene & 5.04 & 25.72 & 1.95 \\
\hline 3 & 4.469 & Camphene & 16.94 & 1.28 & 5.08 \\
\hline 4 & 4.956 & $\beta$-Pinene & 0.37 & 1.24 & - \\
\hline 5 & 5.090 & $\beta$-Myrcene & 1.57 & 0.41 & 0.51 \\
\hline 6 & 5.552 & 3-Carene & - & 7.71 & - \\
\hline 7 & 5.813 & o-Cymene & - & 0.55 & - \\
\hline 8 & 5.918 & D-Limonene & 1.82 & 1.80 & - \\
\hline 9 & 5.937 & cis-Sabinene & - & - & 4.35 \\
\hline 10 & 5.940 & $\alpha$-Phellandrene & 1.76 & - & - \\
\hline 11 & 5.998 & Eucalyptol & 1.31 & 0.83 & 2.60 \\
\hline 12 & 7.156 & $\alpha$-Terpinolene & 0.46 & 0.86 & 0.26 \\
\hline 13 & 7.317 & Linalool & 0.51 & - & 0.32 \\
\hline 14 & 8.867 & endo-Borneol & 0.38 & 0.45 & 1.04 \\
\hline 15 & 9.319 & $\alpha$-Terpineol & - & 0.53 & 0.57 \\
\hline 16 & 10.343 & Neral & 0.74 & - & - \\
\hline 17 & 10.928 & Citral & 1.03 & 0.23 & - \\
\hline 18 & 11.306 & Bornyl acetate & 0.69 & - & - \\
\hline 19 & 11.502 & Carvacrol & - & 1.01 & - \\
\hline 20 & 12.658 & 3-Allylguaiacol & - & 1.28 & - \\
\hline 21 & 13.114 & Copaene & 0.58 & 0.39 & 0.82 \\
\hline 22 & 13.381 & $\beta$-Elemene & 0.58 & 0.41 & 1.34 \\
\hline 23 & 13.957 & Caryophyllene & - & 0.82 & - \\
\hline 24 & 14.116 & $\gamma$-Elemene & - & - & 0.98 \\
\hline 25 & 14.402 & (E)- $\beta$-Famesene & - & - & 0.55 \\
\hline 26 & 14.655 & Ethyl cinnamate & - & 1.22 & - \\
\hline 27 & 14.956 & $\alpha$-Curcumene & 11.62 & 11.88 & 10.68 \\
\hline 28 & 15.091 & Pentadecane & - & 2.19 & - \\
\hline 29 & 15.065 & Germacrene D & - & - & 2.36 \\
\hline 30 & 15.200 & $\alpha$-Zingiberene & 22.89 & 8.01 & 24.88 \\
\hline 31 & 15.348 & $\alpha$-Farnesene & 4.46 & 2.70 & 6.93 \\
\hline 32 & 15.435 & $\beta$-Bisabolene & 9.07 & 6.24 & 11.20 \\
\hline 33 & 15.455 & $\beta$-curcumene & - & 0.51 & - \\
\hline 34 & 15.608 & cis-Muurola-4(15),5-diene & - & - & 0.88 \\
\hline 35 & 15.705 & $\beta$-sesquiphellandrene & 11.21 & 6.81 & 13.67 \\
\hline 36 & 15.834 & trans- $\gamma$-bisabolene & - & - & 0.69 \\
\hline 37 & 16.186 & Elemol & - & 0.42 & 0.95 \\
\hline 38 & 16.283 & trans-Nerolidol & - & 0.56 & 0.59 \\
\hline 39 & 17.203 & Zingiberenol & - & 0.40 & 0.79 \\
\hline
\end{tabular}


Table 1 Chemical compositions of the commercial GEOs, - Continued-

\begin{tabular}{cccccc}
\hline \multirow{2}{*}{ No. } & Rt $(\mathbf{m i n})$ & Compounds & \multicolumn{3}{c}{$\%$ Area } \\
\cline { 3 - 6 } & & & GEO1 & GEO2 & GEO3 \\
\hline 40 & 17.480 & $\beta$-Acorenol & - & 0.98 & - \\
41 & 17.482 & 7 -epi-cis-Sesquisabinene hydrate & 0.33 & - & 0.69 \\
42 & 17.620 & Aromandendrene & - & 0.55 & - \\
43 & 17.974 & $\beta$-Eudesmol & - & 0.52 & - \\
44 & 18.044 & aR-Turmerone & - & 4.65 & - \\
45 & 18.116 & Tumerone & - & 1.08 & - \\
46 & 18.646 & Curlone & - & 1.55 & - \\
47 & 19.450 & Ethyl $p$-methoxycinnamate & - & 1.82 & - \\
\hline
\end{tabular}

Table 2 Antibacterial activity of GEOs

\begin{tabular}{ccccccccccc}
\hline \multirow{2}{*}{ Sample } & \multicolumn{8}{c}{ Diameter of Inhibition Zone (mm)* } \\
\cline { 2 - 11 } & \multicolumn{1}{c}{ S. aureus ATCC 13420 } & E. coli ATCC 9637 & \multicolumn{3}{c}{ B. subtilis } \\
\hline GEO1 & 7.60 & \pm & 0.24 & 0.00 & \pm & 0.00 & 7.97 & \pm & 0.33 \\
GEO2 & 7.17 & \pm & 0.05 & 7.85 & \pm & 0.31 & 7.42 & \pm & 0.02 \\
GEO3 & 7.30 & \pm & 0.08 & 7.20 & \pm & 0.08 & 8.37 & \pm & 0.33 \\
Antibiotic control\# & 21.52 & \pm & 0.22 & 17.63 & \pm & 0.13 & 14.32 & \pm & 0.30 \\
\hline
\end{tabular}

differences in the results may be attributed to the difference in assay methods employed in these studies. The physicochemical properties may affect the diffusion of the oil component into the agar, which interferes with the result. Dilution of the GEO to a surfactant may help to increase the diffusion ability and lower the density of the oil, which in turn may improve the antibacterial activity (Li et al. 2015).

The antimicrobial activity of ginger GEOs has been attributed to these chemical constituents, namely $\beta$ sesquiphellandrene, caryophyllene, $\alpha$-zingiberene, $\alpha$ farnesene, ar-curcumene, citral, $\beta$-bisabolene, geranyl acetate, and geraniol (Mahboubi 2019). These compounds were identified in the GEOs tested; thus, it is likely that the diffusion of the oils to the agar media was not optimal, which resulted in the lower antibacterial activity than expected. In addition, it is also likely that the lower abundance of phenolic compounds contributed to the weak antibacterial activity. This finding is in accordance with a previous study by Pintatum et al. (2020) where Z . kerrii extracts with fewer phenolic compounds did not display good antibacterial activity.

It is also interesting to note that for GEO1, $S$. aureus and $B$. subtilis were more susceptible to GEO1 compared to $E$. coli as no DIZ was observed against $E$. coli. This finding is similar to a previous study where extracted ginger GEO exhibited a better antibacterial activity against $S$. aureus than E. coli, potentially attributed to the structure of Gram-negative bacteria that provides an additional protective barrier against antimicrobial compounds (Wang et al. 2020). Other studies also revealed that GEO had a better antibacterial activity against $S$. aureus compared to $E$. coli (Bellik 2014; Mahboubi 2019; Mesomo et al. 2013). The variation in the antibacterial activities of the three GEOs is likely to be influenced by the differences in the overall chemical compositions detected (Mahboubi 2019), which may play different roles in exerting their activities against the tested bacterial strains. Afterall, ginger GEOs can affect bacterial viability via multiple mechanisms, namely by disrupting the cell membrane permeability, interfering with the respiratory metabolism, and inhibiting DNA metabolism activities (Wang et al. 2020).

The antioxidant activity of GEOs in the present study was tested using DPPH and ABTS methods. The higher $\mathrm{IC}_{50}$ values obtained using DPPH compared to ABTS method (Fig 2) is also similar to the results obtained in a previous study by Höfer et al. (2015) where a number of methods measuring the antioxidant activity of GEO were employed. GEO was found to be 
a weak DPPH reducer compared to BHT (Höferl et al. 2015), thus the use of other methods may elaborate further on the antioxidant activity of GEOs tested in this study. Different plant essential oils may exhibit varying antioxidant activity when different tests are employed, as the chemical compositions of the essential oils are also different and may exert antioxidant activity by various mechanisms (Miguel 2010).

Plants secondary metabolites that contributed to the antioxidant activities are from the phenolic groups (Minatel et al. 2017), which play an important role in neutralizing the free radicals and inhibiting oxidative damage (Pintatum et al. 2020). Phenolic compounds are the main components that play a role in the antioxidant activity of ginger (Yeh et al. 2014). As such, phenolic compounds correlate with the antioxidant activity, as exemplified in a study by Pintatum et al. (2020), where a lower abundance of phenolic compounds compared to terpenoid compounds in $Z$. kerrii extract was suggested to be associated with the weak antioxidant activity observed.

The present study showed intriguing result that the antioxidant activity of GEO2 was the highest, considering that the major component found was $\alpha$ pinene, a non-phenolic compound. Despite weak antioxidant activity as tested with DPPH and ABTS methods observed in a range of plant essential oils when low levels or absence of phenolic compounds are detected (Miguel 2010), a study on essential oils from different plant parts of Myrtus communis var italica showed the lack of phenolic compounds and the presence of $\alpha$-pinene still translated into antioxidant activity (Wannes et al. 2010). Furthermore, it is also likely that the presence of some oxygenated monoterpenes such as carvacrol and $\alpha$-terpineol (albeit in small amounts) may also contribute to the antioxidant activity of GEO2, as such compounds have been attributed to antioxidant activity of essential oils (Bayala et al. 2014).

The chemical constituents of GEOs primarily consist of monoterpene and sesquiterpene compounds. The most abundant compound present in GEOs from Zingiber officinale was $\alpha$-zingiberene at $22.89 \%$ and $24.88 \%$ concentrations for GEO1 and GEO3, respectively. In comparison, GEO2 constituted $\alpha$ pinene $(25.72 \%)$ as the main component.

The GEOs showed low antibacterial and antioxidant activities compared to the respective positive controls. The low antibacterial activity observed in this study was likely caused by the dense characteristic of the oil that caused difficulty to diffuse into the agar media. Therefore, it is recommended to mix the GEOs with surfactant and use a dilution method to evaluate the antibacterial activity. Meanwhile, the low antioxidant activity of the GEOs may be due to the few phenolic compounds present. As different combinations of compounds may contribute to antioxidant activity, it would be desired to perform additional methods to assess antioxidant activity to obtain a better insight into which compounds are likely to play a role in antioxidant activity in the GEOs tested.

\section{ACKNOWLEDGEMENTS}

Sincere gratitude is extended to the Ministry of Research and Technology/National Research and Innovation Agency for the research grant Riset Inovatif Produktif/RISPRO scheme No. 164/E1/PRN/2020 entitled "Development of essential oil standardization method through the determination of antiaging and antioxidant active compounds utilizing chemometric analysis". This work was also supported by the Riset Inovatif Produktif/RISPRO Mandatory Grant for COVID-19 No: 8/FI/P-KCOVID-19.2B3/X/2021.

\section{REFERENCES}

Abd El-Hack ME, Alagawany M, Shaheen H, Samak D, Othman SI, Allam AA, Taha AE, Khafaga AF, Arif M, Osman A, El Sheikh AI, Elnesr SS, Sitohy M. 2020. Ginger and its derivatives as promising alternatives to antibiotics in poultry feed. Animals. 10(3):452. doi: 10.3390/ani10030452.

Anh NH, Kim SJ, Long NP, Min JE, Yoon YC, Lee EG, Kim M, Kim TJ, Yang YY, Son EY, Yoon SJ, Diem NC, Kim HM, Kwon SW. 2020. Ginger on human health: A comprehensive systematic review of 109 randomized controlled trials. Nutrients. 12(1):157. doi: 10.3390/nu12010157.

Bag A, Chattopadhyay RR. 2015. Evaluation of synergistic antibacterial and antioxidant efficacy of essential oils of spices and herbs in combination. PLoS One. 10(7):e0131321. doi: 10.1371/journal.pone.0131321.

Bampidis V, Azimonti G, Bastos M de L, Christensen H, Durjava MK, Kouba M, López-Alonso M, Puente SL, Marcon F, Mayo B, Pechová A, Petkova M, Ramos F, Sanz Y, Villa RE, Woutersen R, Brantom P, Chesson A, Westendorf J, Gregoretti L, Manini P, Dusemund B. 2020. Safety and efficacy of essential oil, oleoresin and tincture from Zingiber officinale Roscoe when used as sensory additives in feed for all animal species. EFSA J. 18(6):e06147. doi: 10.2903/j.efsa.2020.6147. 
Bayala B, Bassole IH, Gnoula C, Nebie R, Yonli A, Morel L, Figueredo G, Nikiema JB, Lobaccaro JM, Simpore J. 2014. Chemical composition, antioxidant, antiinflammatory and anti-proliferative activities of essential oils of plants from Burkina Faso. PloS One. 9(3): e92122. doi: 10.1371/journal.pone.0092122.

Bellik Y. 2014. Total antioxidant activity and antimicrobial potency of the essential oil and oleoresin of Zingiber officinale Roscoe. Asian Pac J Trop Dis. 4(1):40-44. doi: 10.1016/S2222-1808(14)60311-X.

Bhuiyan MNI, Chowdhury JU, Begum J. 2008. Volatile constituents of essential oils isolated from leaf and rhizome of Zingiber cassumunar Roxb. Bangladesh J Pharmacol.3(2):69-73. doi: 10.3329/bjp.v3i2.844.

Höferl M, Stoilova I, Wanner J, Schmidt E, Jirovetz L, Trifonova D, Stanchev V, Krastanov A. 2015. Composition and comprehensive antioxidant activity of ginger (Zingiber officinale) essential oil from E c u a d o r. N a t P r o d o m m n. 10 ( 6 ): $1934578 \times 1501000672$. doi: $10.1177 / 1934578 X 1501000672$.

Kamaliroostaa Z, Kamaliroosta L, Elhamirad A. 2013. Isolation and identification of ginger essential oil. $\mathrm{J}$ FBT, IAU. 3:73-80.

Koga AY, Beltrame FL, Pereira AV. 2016. Several aspects of Zingiber zerumbet: A review. Revista Brasileira de Farmacognosia, 26(3):385-391. doi: 10.1016/j.bjp. 2016.01.006.

Kun-Hua W, Jian-Hua M, He-Ping H, Shan-Lin G. 2011. Generation of autotetraploid plant of ginger (Zingiber officinale Rosc.) and its quality evaluation. Pharmacogn Mag. 7(27):200-206. doi: 10.4103/09731296.84230

Li W, Chen H, He Z, Han C, Liu S, Li Y. 2015. Influence of surfactant and oil composition on the stability and antibacterial activity of eugenol nanoemulsions. LWTFood Sci Technol. 62(1): 39-47. doi: 10.1016/j.lwt. 2015.01.012.

Lobo V, Patil A, Pathak A, Chandra N. 2010. Free radicals, antioxidants and functional foods: Impact on human health. Pharmacogn Rev. 4(8):118-126. doi: 10.4103/0973-7847.70902.

Lyu JI, Ryu J, Jin CH, Kim D-G, Kim JM, Seo K-S, Kim J-B, Kim SH, Ahn J-W, Kang S-Y, Kwon S-J. 2020. Phenolic compounds in extracts of Hibiscus acetosella (Cranberry Hibiscus) and their antioxidant and antibacterial properties. Molecules. 25(18):4190. doi: 10.3390/molecules25184190.

Mahboubi M. 2019. Zingiber officinale Rosc. essential oil, a review on its composition and bioactivity. Clin Phytoscience. 5(1):1-12. doi:10.1186/s40816-0180097-4.

Manochai B, Paisooksantivatana Y, Choi H, Hong JH. 2010.
Variation in DPPH scavenging activity and major volatile oil components of cassumunar ginger, Zingiber montanum (Koenig), in response to water deficit and light intensity. Sci. Hortic. 126(4):462-466 doi: 10.1016/j.scienta.2010.07.011.

Mao Q-Q, Xu X-Y, Cao S-Y, Gan R-Y, Corke H, Beta T, Li H-B. 2019. Bioactive compounds and bioactivities of ginger (Zingiber officinale Roscoe). Foods. 8(6):185. doi: 10.3390/foods 8060185 .

Meliani A, Nair S, Bensoltane A. 2014. Cyto-biochemical and antimicrobial investigations on essential oil of Zingiber officinale Roscoe. J Essent Oil-Bear Plants. 17(6):1120-1129. doi: 10.1080/0972060X. 2014.986540

Mesomo MC, Corazza ML, Ndiaye PM, Dalla Santa OR, Cardozo L, Scheer A de P. 2013. Supercritical CO2 extracts and essential oil of ginger (Zingiber officinale R.): Chemical composition and antibacterial activity. J Supercrit Fluids . 80:44-49. doi: 10.1016/j.supflu.2013.03.031.

Miguel MG. 2010. Antioxidant and anti-inflammatory activities of essential oils: a short review. Molecules. 15(12):9252-9287. doi: 10.3390/molecules15129252.

Minatel IO, Borges CV, Ferreira MI, Gomez HAG, Lima CYOC and GPP. 2017. Phenolic compounds: functional properties, impact of processing and bioavailability. IntechOpen. doi: 10.5772/66368.

Mostafa AA, Al-Askar AA, Almaary KS, Dawoud TM, Sholkamy EN, Bakri MM. 2018. Antimicrobial activity of some plant extracts against bacterial strains causing food poisoning diseases. Saudi J Biol Sci. 25(2):361-366. doi: 10.1016/j.sjbs.2017.02.004.

Pintatum A, Laphookhieo S, Logie E, Berghe WV, Maneerat W. 2020. Chemical composition of essential oils from different parts of Zingiber kerrii Craib and their antibacterial, antioxidant, and tyrosinase inhibitory activities. Biomolecules. 10(2):228. doi: 10.3390/biom 10020228 .

Rana VS, Ahluwalia V, Shakil NA, Prasad L. 2017. Essential oil composition, antifungal, and seedling growth inhibitory effects of zerumbone from Zingiber zerumbet Smith. J Essent Oil Res. 29(4):320-329 doi: 10.1080/10412905.2016.1261051.

Ribeiro A, Estanqueiro M, Oliveira M, Sousa Lobo J. 2015. Main benefits and applicability of plant extracts in skin care products. Cosmetics. 2(2):48-65 doi: 10.3390/cosmetics2020048.

Silva FT da, Cunha KF da, Fonseca LM, Antunes MD, Halal SLME, Fiorentini ÂM, Zavareze E da R, Dias ARG. 2018. Action of ginger essential oil (Zingiber officinale) encapsulated in proteins ultrafine fibers on the antimicrobial control in situ. Int $\mathrm{J}$ of Biol Macromol. 118(PtA):107-115. doi: 10.1016/j.ijbiomac. 
2018.06.079.

Sharma PK, Singh V, Ali M. 2016. Chemical composition and antimicrobial activity of fresh rhizome essential oil of Zingiber officinale Roscoe. Pharmacogn J. 8(3):185-190. doi: 10.5530/pj.2016.3.3.

Sivasothy Y, Chong WK, Hamid A, Eldeen IM, Sulaiman SF, Awang K. 2011. Essential oils of Zingiber officinale var. rubrum Theilade and their antibacterial activities. Food Chem. 124(2):514-517. doi: 10.1016/j.foodchem .2010.06.062.

Stoyanova A, Konakchiev A, Damyanova S, Stoilova I, Suu PT. 2006. Composition and antimicrobial activity of ginger essential oil from Vietnam. J Essent Oil-Bear Plants. 9(1):93-98. doi: 10.1080/0972060X. 2006.10643478.

Wang X, Shen Y, Thakur K, Han J, Zhang J-G, Hu F, Wei Z-J. 2020. Antibacterial activity and mechanism of ginger essential oil against Escherichia coli and Staphylococcus aureus. Molecules. 25:3955. doi: 10.3390/molecules25173955.

Wannes W, Mhamdi B, Sriti J, Jenia MB, Ouchikh O, Hamdaoni G, Kchouk ME, Marzouk B. 2010. Antioxidant activities of the essential oils and methanol extracts from myrtle (Myrtus communis var. italica) leaf, stem and flower. Food Chem Toxicol. 48:13621370. doi: 10.1016/j.fet.2010.03.002.

Yeh H, Chuang C, Chen H, Wan C, Chen T, Lin L. 2014. Bioactive components analysis of two various gingers (Zingiber officinale Roscoe) and antioxidant effect of ginger extracts. LWT- Food Sci Technol. 55:329-334. doi: 10.1016/j.lwt.2013.08.003.

Yen G-C, Chen H-Y. 1995. Antioxidant activity of various tea extracts in relation to their antimutagenicity. J Agri Food Chem. 43(1):27-32. doi: 10.1021/jf00049a007. 